\title{
Functions and Failures of Transnational Activism: Discourses of Children's Resistance and Repression in Global Anti-Apartheid Networks
}

In the mid-1980s, two activist groups involved in the global anti-apartheid struggle rose to prominence: in South Africa's townships, child and youth activists known as "the comrades" came to the forefront of the grassroots liberation movement, while in Britain, the visibility and influence of the Anti-Apartheid Movement (AAM) increased dramatically. As state repression escalated in South Africa following the declaration of a state of emergency in July 1985, these seemingly disparate groups became increasingly connected. As child and youth activists were beaten, detained, and tortured by the thousands, their suffering became a subject of primary concern for the AAM who launched a campaign to investigate and globally disseminate information about the brutality inflicted against them. The abuse of children proved to be a particularly emotive topic which earned the AAM unprecedented domestic media attention and influence with the British government.

Since history's recent "global turn", the concept of "networks" has been particularly adept at enabling historians to see the reciprocal connections between local and global actors, and to bridge the increasingly artificial divide between regional, national, and international spaces. ${ }^{1}$ Studying imperial and global networks allows one to see not only the flows of commodities, power and ideas between empires and their current or former colonies, but also the lateral movements between different metropoles or peripheries. The worldwide campaign against

\footnotetext{
${ }^{1}$ David Bell, "This Is What Happens When Historians Overuse the Idea of the Network", New Republic, [online], http://www.newrepublic.com/article/114709/world-connecting-reviewedhistorians-overuse-network-metaphor, accessed 7 November 2014.
} 
apartheid offers insight into how such connections are forged and sustained, as it was "perhaps the most influential of all global social movement of the late twentieth century," and an "early manifestation of a new kind of globalizing process." ${ }^{2}$ Britain's AAM sat at the heart of this transnational advocacy network throughout the later twentieth century. Central to its functioning was its distribution of information about apartheid's worst abuses, which it received from various local South African actors and disseminated to its members, the British public and concerned organisations across the globe. From the mid-1980s onwards, stories of children as targets of state repression became a central narrative circulating through this network, as the AAM publicised statistics and testimonies of human rights abuses collected from victims on the ground. Advocacy networks are dependent on such an "international commitment to narrability" in order to function successfully, and it was ultimately only through such efforts that news of child resistance and repression was made public in Britain, as all media coming out of South Africa was heavily censored at the time. ${ }^{3}$

As fruitful as the concept of "networks" has been for understanding such connections, its use in historical scholarship is not without limitations. While globalisation discourse has been particularly influential in the field over the last two decades, it is nevertheless "deeply

${ }^{2}$ Saunders, "The Anti-Apartheid Movement and the Emergence of a Global Conscience," Journal of Southern African Studies 36 (2010): 729; Peter Limb, Richard Knight and Christine Root, "The Global Antiapartheid Movement: A Critical Analysis of Archives and Collections," Radical History Review 119 (2014): 161.

${ }^{3}$ Kay Schaffer and Sidonie Smith, Human Rights and Narrated Lives: The Ethics of Recognition (Basingstoke: Palgrave Macmillan, 2004), 3. 
misleading...for assuming coherence and direction instead of probing causes and processes." 4 Consequently, Frederick Cooper argues, not enough attention has been paid to the actual functioning and limitations of networks. When advocacy networks disseminate knowledge, they frame the issues at hand in ways that make them accessible and persuasive to public audiences. In the process, the original narratives of local actors are often made to "fit" with favourable institutional values or shared moral principles. ${ }^{5}$ Subsequently, they are restructured or even coopted by global actors, recounted in simplistic binaries of right and wrong, and abstracted from their original cultural and political contexts. Furthermore, many transnational networks that rise to prominence or become successful are distinctly Anglophone or led by Western elites, shielding from popular or academic view networks forged between non-English speaking actors or without ties to the "first world".

South African child activists' own narratives, recorded both at the time and several decades later in oral history interviews, place emphasis on their agency, ideological commitments, and coping mechanisms, and clearly present themselves as "heroes" rather than "victims" in the struggle against apartheid. Yet as these narratives were collected and distributed by the AAM in the mid-1980s, they were rewritten for global consumption; through each phase of transmission - from the children themselves, to humanitarian organisations collecting their stories, to the AAM, and finally to British media outlets - their stories were incrementally

\footnotetext{
${ }^{4}$ Frederick Cooper, "What is the Concept of Globalization Good For? An African Historian's Perspective," African Affairs 100 (2001): 189.

${ }^{5}$ Margaret E. Keck and Kathryn Sikkink, Activists beyond Borders: Advocacy Networks in International Politics (Ithaca and London: Cornell University Press, 1998), 2; 19.
} 
generalised and removed of historical specificity, and reframed according to two particular arenas of western moral concern: human rights and child victimisation. Drawing on assumptions of childhood as a period of vulnerability and naivety, the AAM constructed the comrades as passive victims in the struggle against apartheid, favouring decontextualised narratives of child victimisation over activists' own narratives of their political precocity, agency, and responsibility.

The dissonance between these two discourses reflects the imbalance within many transnational networks. While the connections forged between local activists and those campaigning against apartheid in Britain were not unilateral, with knowledge and information flowing reciprocally, the network they formed was nevertheless asymmetrical. As Katherine Bruce-Lockhart also highlights in this volume, the fact that transnational networks share a common purpose does not necessarily translate to agreement or consent between their diverse actors. Critiques of transnational advocacy as simply a new form of cultural imperialism may be too strong, but these networks nevertheless continue to privilege the connected over the disconnected, exposing the uneven processes and rewards of globalisation. Didier Fassin argues that while the politics of humanitarianism is a politics of solidarity, it is also a politics of inequality; "When compassion is exercised in the public space, it is therefore always directed from above to below, from the more powerful to the weaker, the more fragile, the more vulnerable."

This article analyses the strategic use of discourse by a range of local and global activists involved in anti-apartheid networks, contrasting narratives of childhood activism targeted at

${ }^{6}$ Didier Fassin, Humanitarian Reason: A Moral History of the Present, trans. Rachel Gomme (Berkeley: University of California Press, 2012), 4. 
western audiences with the memories of South Africa's former young activists themselves, utilising both archival records and oral history testimony. It particularly focuses on the efforts of the British anti-apartheid movement, and thus does not provide detailed analysis of other countries' involvement in South Africa's liberation struggle. ${ }^{7}$ In doing so, it reflects on the ways in which different sources privilege different voices, and highlights, as Felicity Barry does in this volume, the persistent paucity of individual, subaltern and disconnected narratives in imperial and global histories. In order to counter such tendencies, global history needs to incorporate methodologies pioneered by social and postcolonial historians in the 1970s, such as oral history, linguistics and the borrowing of anthropological methods. Such methods are essential to the future of global history, as only by uncovering the experiences of the local and elevating them above the regional frameworks that conventionally contain them can history claim to be truly global.

The AAM and Transnational Advocacy Networks

Despite the recent popularity of global approaches to history, considerable paucities remain in understanding the functions and failures of transnational networks. In the South African case, much work on the anti-apartheid struggle tends to neatly divide internal and external factors, with little analysis of how these were intrinsically linked. ${ }^{8}$ Repeated calls have been made by

${ }^{7}$ For more on the AAM outside of Britain, see Radical History Review 119 (2014) and SADET ed., The Road to Democracy in South Africa: Volume 3: International Solidarity, (Pretoria: UNISA, 2008).

${ }^{8}$ Hakan Thörn, Anti-Apartheid and the Emergence of a Global Civil Society (Basingstoke: Palgrave Macmillan, 2006), 3. 
historians to address this persistent disconnection. In 1990, Shula Marks stated, "ways have to be found of unifying 'history from above' with 'history from below'"9 Twenty-three years later, Hilary Sapire reiterated,

The challenge now remains to develop a historical synthesis of South Africa's liberation struggle that takes full cognisance of its changing rhythms and dynamics within and without the country and the precise nature of the linkages between exiled movements, the armed struggle and township-based activists, between national and local associations, and between elites and the local grassroots over a long period. ${ }^{10}$

Recently, academics have begun to address the global nature of the AAM and discuss the movement in terms of "networks of solidarity" that traversed national borders and presaged a more globalised world. ${ }^{11}$ Despite the beginnings of this paradigm shift, there is still little investigation into how effective these networks were or whether they functioned as intended.

${ }^{9}$ Shula Marks, "History, the Nation and Empire: Sniping from the Periphery," History Workshop 29 (1990): 116.

${ }^{10}$ Hilary Sapire, "Township Histories, Insurrection and Liberation in Late Apartheid South Africa," South African Historical Journal 65 (2013): 170.

${ }^{11}$ See Radical History Review 119 (2014): 1-252. Also Gay Seidman, “Adjusting the Lens: What Do Globalizations, Transnationalism, and the Anti-apartheid Movement Mean for Social Movement Theory?" in Globalizations and Social Movement: Culture, Power, and the Transnational Public Sphere, ed. John A. Guidry, Michael D. Kennedy and Mayer N. Zald (Ann Arbor: University of Michigan Press, 2000), 339-357. 
While both the "comrades" and AAM have been studied in depth, ${ }^{12}$ the nature of connections between the two remains unexplored.

According to Keck and Sikkink, a transnational advocacy network is a system of states, non-state actors, and international organisations working together on an international issue "bound together by shared values, a common discourse, and dense exchanges of information and services." ${ }^{13}$ While such networks are not necessarily a new feature of modern globalisation (an oft-cited earlier example is the abolitionist movement), their size, speed, and complexity have grown considerably over the past three decades. Central to networks' functioning is the exchange of information between actors; a network's "ability to generate information quickly and accurately, and deploy it effectively, is their most valuable currency." 14 This was certainly the case for the AAM, which rose to prominence concurrently with media's globalisation, and used

${ }^{12}$ For the former see Colin Bundy, "Street Sociology and Pavement Politics: Aspects of Youth and Student Resistance in Cape Town, 1985," Journal of Southern African Studies 13 (1987): 303-330; Ari Sitas, "The Making of the 'Comrades' Movement in Natal, 1985-91," Journal of Southern African Studies 18:3 (1992): 629-641; Jeremy Seekings, Heroes or Villains? Youth Politics in the 1980s, (Johannesburg: Raven Press, 1993). And for the latter: Thörn, AntiApartheid; Roger Fieldhouse, Anti-Apartheid: A History of the Movement in Britain (London: Merlin Press, 2005); Rob Skinner, The Foundations of Anti-Apartheid: Liberal Humanitarians and Transnational Activists in Britain and the United States, c. 1919-64 (Basingstoke: Palgrave Macmillan, 2010).;The Road to Democracy in South Africa: Volume 3: International Solidarity.

${ }^{13}$ Keck and Sikkink, Activists beyond Borders, 2.

${ }^{14}$ Ibid., 10. 
the dissemination of statistics, stories, and images to shape public opinion and alter government policy. By the 1980s, publicity dominated the work of the AAM, which produced a monthly publication (The Anti-Apartheid News), organised national information tours and conferences, and provided articles or briefings to the press.

It was through the collection and dissemination of information that the AAM forged connections with South Africa's young comrades. Under emergency regulations, the apartheid government had no obligation to disclose information about its political detainees. Consequently, little news of the repression of young activists circulated freely through global communication channels. From the mid-1980s the AAM worked closely with several local and global humanitarian organisations striving to uncover the truth about South Africa's child detainees; groups such as the Detainees Parents Support Committee (DPSC), the International Defence and Aid Fund (IDAF), the New York Lawyers Committee for Human Rights, and the Black Sash collected affidavits from detained activists following their release and compiled lists of those still in detention. They then sent their reports to the AAM, which circulated the information in AntiApartheid News and several mainstream domestic newspapers. Occasionally, AAM members themselves were sent on fact-finding missions to South Africa. The figures that began to emerge after two years of emergency regulations were staggering: from 1984 to 1986, 300 children were killed by police, 1000 wounded, 11,000 detained without trial, 18,000 arrested on charges due to protest, and 173,000 held in police cells while awaiting trial. ${ }^{15}$ Approximately forty percent of all

\footnotetext{
${ }^{15}$ Leslie Swartz and Ann Levett, 'Political Oppression and Children in South Africa: the Social Construction of Damaging Effects,' in Political Violence and the Struggle in South Africa, ed. N. Chabani Manganyi and André du Toit (London: Macmillan, 1990), 265.
} 
detainees were under eighteen-years-old. ${ }^{16}$ When quoted in the Anti-Apartheid News and British press, these figures were often accompanied by personalised stories of abuse. The Guardian declared South Africa's "war against children" to be the most alarming story to emerge during the state of emergency, and detailed the forms of abuse common in detention, including assaults with fists, feet, sjamboks (heavy leather whip), and rifle butts, and suffocation with hands or hoods tied tightly around children's necks. ${ }^{17}$ The Times told similar stories, including that of one child "held down in water into which teargas has been pumped."18

\section{Information Framing: Human Rights and Child Victimization}

A central facet of networks' dissemination of information is how issues are purposefully "framed" to make them more accessible to public audiences. In preparation for public consumption, complex issues are simplified into neat binaries of right and wrong. Consequently there is often "a huge gap between the story's original telling and the retellings." 19 While transnational networks forge connections between diverse actors in the North and South, they also tend to privilege the connected over the disconnected in pursuit of a cohesive narrative, and, as a result, local actors often lose control over their stories in global campaigns.

\footnotetext{
${ }^{16}$ Historical Papers, Johannesburg, AG2523: S4.1: B3, National Medical and Dental Association, “The Treatment of Detainees,” April 1987.

${ }^{17}$ David Beresford, "South Africa's War on Children,” The Guardian, 28 November 1986.

${ }^{18}$ Michael Hornsby, "South African Rights Group Claims Torture of Children is Widespread," The Times, 16 October 1986.

${ }^{19}$ Keck and Sikkink, Activists Beyond Borders, 2; 19.
} 
As child activists' narratives were readied for publication, they were framed according to two particular areas of recent global concern. First, the repression of children was portrayed as a human rights issue, rather than a racial or political one. This strategy had proved effective in the AAM's previous political prisoner campaigns in the late $1970 \mathrm{~s} .{ }^{20}$ Its particular timing was not insignificant, as international concern for human rights grew considerably in the latter decades of the twentieth century. The proliferations of rights-based nongovernmental organisations in the 1970s and 1980s transformed human rights from an "empty declaration" into an "influential and forceful political discourse." ${ }^{21}$ Fassin contends that consequently, a new moral economy arose based on the principles of humanitarian reason, in which humanitarian discourse, with its emphasis on suffering and misfortune, became particularly successful at generating public support. $^{22}$

By framing stories within this popular discourse, the AAM was able to make broader and more persuasive appeals to the British public and government, as human rights were a less politically volatile cause than supporting the armed struggle or a left-wing liberation movement,

${ }^{20}$ Genevieve Klein, “The British Anti-Apartheid Movement and Political Prisoner Campaigns, 1973-1980," Journal of Southern African Studies, 35:2 (2009): 455-456.

${ }^{21}$ Keck and Sikkink, Activists Beyond Borders, 89-90. See also Akira Irive, Petra Goedde, and William I. Hitchcock, ed., The Human Rights Revolution: An International History (New York: Oxford University Press, 2012); Aryeh Neier, The International Human Rights Movement (Princeton: Princeton University Press, 2012).

${ }^{22}$ Fassin, Humanitarian Reason, 3-7. 
and stood above Cold War rivalries. ${ }^{23}$ Media editors too were more willing to publish stories of human rights abuses than those about South African liberation leaders. Victoria Brittain, an AAM member and Guardian journalist, commented that the British media and AAM had a tense relationship, as the press perceived the movement to be an adjunct of the ANC, and were thus sceptical of its motivations and uninterested in publishing its stories. ${ }^{24}$ The movement thus had to draw on areas of wider public concern to gain media attention. In The Guardian, Brittain directly compared South African children to the victims of the Holocaust - the event most credited with sparking the international community into action in regards to protecting human rights. ${ }^{25} \mathrm{By}$ focusing on stories of human rights abuses rather than those of political leaders, the AAM gained unprecedented media attention in the mid-1980s. Additionally, by framing certain issues as rights violations, the AAM expanded its already vast network, forging connections with a range of national and international humanitarian organisations.

Secondly, the AAM emphasized the vulnerability, innocence, and "child" status of young detainees, thus framing its information according to emotive and morally incontestable claims. As Manganyi and du Toit state, "These images of children as victims of political violence are so

${ }^{23}$ Klein, "Political Prisoner Campaigns," 459; Akira Irive and Petra Goedde, "Introduction: Human Rights as History," in The Human Rights Revolution: An International History (New York: Oxford University Press, 2012), 9.

24 Victoria Brittain, interviewed by Håkan Thörn, 5 February 2000, reproduced on the AntiApartheid Movement Archives Committee Forward to Freedom project website http://www.AAMarchives.org/, accessed on 20 August 2014.

${ }^{25}$ Victoria Brittain, "A generation that is living in terror," The Guardian, 2 October 1987. 
powerful precisely because they express legitimate and widely shared concerns: surely nobody should want to see innocent children harmed, and evidently society has a great stake in the future of its children." ${ }^{26}$ The timing of this emphasis was also significant. While international child saving has a long history, particular global concern over "Third World" children arose during the 1970s, largely due to global media dissemination of images of suffering children in Ethiopia, Sudan, and Latin America. ${ }^{27}$ The year 1979 was subsequently declared the International Year of the Child, as the concept of "the world's children" emerged in the official discourse of aid agencies such as UNICEF and the WHO. ${ }^{28}$ Moreover, as images of abused children proliferated in anti-apartheid literature, on-going efforts were being made by the international community to draft the United Nations Convention on the Rights of the Child (UNCRC), which was formally adopted in 1989. The international children's rights regime mobilised by the AAM drew on the

${ }^{26}$ N. Chabanyi Manganyi and André du Toit, "Editorial Introduction," in Political Violence and the Struggle in South Africa, ed. N. Chabani Manganyi and André du Toit (London: Macmillan, 1990), 22.

${ }^{27}$ See Katherine Bruce-Lockhart's article in this volume for an example of international concern over 'Third World' children during the colonial period; Dominique Marshall, "International Child Saving," in Routledge History of Childhood in the Western World, ed. Paula S. Fass (Abingdon: Routledge, 2013), 469-490.

${ }^{28}$ Allison James and Alan Prout, "Introduction," in Constructing and Reconstructing Childhood: Contemporary Issues in the Sociological Study of Childhood, ed. Allison James and Alan Prout (London: Falmer Press, 1997), 1. 
Convention's notion of an ideal, universally applicable model of childhood. ${ }^{29}$ However, the construction of childhood as a distinct life stage characterized by dependence, innocence, and immaturity is historically and culturally specific; while it is an honourable notion, it is nevertheless modern and distinctively western. ${ }^{30}$ Under the globalising forces of colonialism and international development, this conceptualisation was exported - often inappropriately - to the global South, where it was criticized for its paternalistic qualities. ${ }^{31}$

\section{Chains of Abstraction: The Victim Narrative}

The application of this western construction of childhood to South Africa's young activists had symbolic and practical consequences in that it denied children political agency, misrepresented and oversimplified events unfolding on the ground, and failed to acknowledge children's own ideological understandings and connections to the communist world. Yet the "comrades", as they were known, were not portrayed uniformly across all levels of information gathered and disseminated by this network. Rather, a chain of abstraction is evident in which activists' own narratives were incrementally rewritten according to the audience in question. In interviews, former child and youth activists place emphasis on their political maturity, ideological

${ }^{29}$ Vanessa Pupavac, "Misanthropy without Borders: The International Children's Rights Regime," Disasters 25:2 (2001): 101.

${ }^{30}$ Paula S. Fass, “Children and Globalization," Journal of Social History 36:4 (2003): 967.

${ }^{31}$ This is evidenced by the African Charter on the Rights and Welfare of the Child. See Afua Twum-Danso Imoh, "The Convention on the Rights of the Child: A Product and Facilitator of a Global Childhood," in Childhoods at the Intersection of the Local and the Global, ed. Afua Twum-Danso Imoh and Robert Ame (Basingstoke: Palgrave Macmillan, 2012), 28-29. 
commitments, and multifaceted forms of protest and direct engagement with the apartheid state. Many of these details are included in reports gathered by local humanitarian or legal organizations working directly with child and youth detainees in the 1980s, such as the DPSC and Black Sash. Particular emphasis was placed in such documents on the Congress of South African Students (COSAS), whose members rose to the forefront of student protests in 1984 and were banned and targeted from 1985. These reports were sent to the AAM headquarters in London, and provided detailed descriptions of COSAS' principles, educational demands, and complex organisational structure. ${ }^{32}$

Next, these reports were summarized and publicised to AAM members through AntiApartheid News. Produced monthly from 1965 to 1994, the publication was designed as "the main propaganda vehicle of the Anti-Apartheid Movement," and was intended to serve as the primary communication channel between the movement and its "grassroots"; to draw to the movement people who previously knew little about apartheid; and to act as an international communications link. ${ }^{33}$ From its inception it was therefore seen as an organ of transmission that would sit at the heart of the AAM's transnational network. COSAS and other activist

${ }^{32}$ AAMA, MMS AAM 1987, Detainee Parents' Support Committee, "The Congress of South African Students," 1984.

${ }^{33}$ Of just under 5500 copies sold in a single month in the 1970s, 2900 were sent to existing AAM members and 2087 to regular bulk orders. This suggests that despite attempts to reach a wider audience, the paper's readership was largely a fixed one, consisting of those already concerned about apartheid. AAMA, MSS AAM 2187, Christabel Gurney, "Report of meeting held to discuss AA News," 11 February (year unknown). 
organisations are mentioned on occasion in Anti-Apartheid News throughout the mid-1980s. While such articles acknowledged the resilience and fortitude of young activists, speaking of their "political maturity" and "crucial roles", they nevertheless removed or downplayed many of the specificities of COSAS ideology contained in DPSC reports. ${ }^{34}$ The tendency to simplify complex conflicts to binaries of good and evil is common to many humanitarian efforts. Within advocacy networks, those who are painted as victims must be constructed as sympathetic and innocent, as "it is virtually impossible to evoke sympathy for a victim who appears villainous, roguish, or unreceptive to a liberal reconstructionist project." ${ }^{35}$ COSAS members' involvement in various forms of political violence were subsequently ignored, as were their socialist political leanings. ${ }^{36}$

The detention of children and youth only became a primary focus of Anti-Apartheid News in early 1987, eighteen months after the declaration of the state of emergency and the banning of COSAS. From this point, the paper published articles on the subject almost monthly until 1989. During this period, a noticeable shift in information framing is evident: stories of young activists were further abstracted from their specific political contexts; detention was increasingly constructed as a human rights issue; and emphasis on "students" or "youth" were gradually

\footnotetext{
${ }^{34}$ AAMA, MMS AAM 2203, Anti-Apartheid News, "In the frontline: youth and students," January/February 1982; AAMA, MMS AAM 2203, Anti-Apartheid News "Student repression finds a swift response,” October 1985.

${ }^{35}$ Makau Mutua, Human Rights: A Political and Cultural Critique (Philadelphia: University of Pennsylvania Press, 2002), 29.

${ }^{36}$ Both of which are spoken about at length by interviewees.
} 
replaced with a specific focus on "children". While the publication did not entirely deny youth agency, with references to "the revolutionary initiative of the young people," or how, despite repression, "the courage and will to resist of South Africa's youth remain undiminished," mentions of activists' political affiliations however became fewer and fewer from 1987 onwards. ${ }^{37}$

In its efforts to reach a broader audience, the AAM sought to influence British media reporting by sending press releases to, or writing articles for, mainstream newspapers. As stories of children's resistance and repression were rewritten for non-specialist and detached audiences, they were further decontextualised. Two particular narratives of South Africa's comrades dominated British media depictions in the 1980s, the first arguably influenced by the biased reporting originating in South Africa, and the second by the AAM's efforts to counter the apartheid state's official narrative. In the first, young activists were portrayed as a homogeneous group of young, threatening males, characterized as an "intimidating," and "alienated generation". ${ }^{38}$ They were likened to the children of Lord of the Flies, and credited with creating a society "equally barbaric and anarchic." ${ }^{39}$ Despite acknowledging some of the comrades' political activities, such narratives removed their agency as deliberate political actors; for only their most violent and brutal actions were mentioned, which were then attributed not to political

${ }^{37}$ AAMA, MSS AAM 2203, Anti-Apartheid News, "Youth in the lead against apartheid torture," January/February 1987; ibid "Children who defy the bullets," May 1987.

${ }^{38}$ Alistair Sparks, "The Comrades take over in Alex," The Guardian, 23 February 1986; David Beresford, "Killing Time in the Playground," The Guardian, 29 May 1986.

${ }^{39}$ David Beresford, "Killing Time in the Playground" 
motivations but to the uncontrollable effects of the mob or adult "agitators" - namely the ANC in exile - who corrupted these otherwise innocent children. ${ }^{40}$ This represented a persistent trend to see politicised children as being co-opted or unduly influenced by adults, and thus not responsible for their actions. ${ }^{41}$

In the second narrative, no mention was made of children's political activities. Rather, all emphasis was placed on their victim status, as they were cast as vulnerable children unfairly targeted by the apartheid state. While the term "comrades" was used to discuss child and youth activists in articles discussing their mob-like tendencies, it was never used in discussions of their detention or torture. There was thus no connection made between the young people fighting against apartheid on township streets, and those detained and brutalised for their involvement in the struggle; the same journalist would one day write of menacing "youths" and the next of innocent "children" with no acknowledgement of the correlations between them. ${ }^{42}$ While some children rounded up in general township sweeps indeed had no political affiliations, most of those in detention centres were comrades with clear ideological motivations. Some of these articles were written directly by AAM members. In The Guardian, Brittain cast young activists as "the victims of South Africa's war against black children...whose future has been shattered."43 This statement overlooked the empowering affects that politicisation and even detention had for

\footnotetext{
${ }^{40}$ Swartz and Levett, "Political Oppression," 268.

${ }^{41}$ Ed Cairns, Children and Political Violence (Oxford: Blackwell, 1996), 108.

${ }^{42}$ See David Beresford, "Killing time in the playground"; "Labour leader claims torture in SA prisons," The Guardian, 23 August 1986.

${ }^{43}$ Victoria Brittain, "A generation that is living in terror," The Guardian, 2 October 1987.
} 
many young people involved in the struggle. Such feelings of empowerment were acknowledged in Anti-Apartheid News, which stated that some children "appear strengthened by their terrible experiences and emerge [from detention] determined to continue the struggle." ${ }^{\prime 4}$ However, this narrative was removed from mainstream media reports.

Brittain's framing of the comrades contrasts directly with the narratives of former youth activists themselves, who - like child soldiers in other contexts - emphasise the positive and lasting effects of their participation in protest and conflict. ${ }^{45}$ The media construction of comrades as "innocent children" denied youth agency, and assumed control over how their stories were quoted or framed. Such reporting, and particularly that by Brittain, can be explained by the tense relationship between the AAM and British press. As AAM leader Mike Terry commented, "There was an underlying element in the media that saw Africans as victims, rather than seeing the African majority as the decisive force for change." 46 After struggling to gain any mainstream media attention during the 1970s, the AAM succeeded in publicising their cause in the mid-

${ }^{44}$ AAMA, MSS AAM 2203, Anti-Apartheid News, “Children who defy the bullets,” May 1987.

${ }^{45}$ See Harry G. West, “Girls with Guns: Narrating the Experience of War of Frelimo's 'Female Detachment," Anthropological Quarterly 73:4 (2000): 185; Paul Richards and Krijn Peters, “"Why We Fight': Voices of Youth Combatants in Sierra Leone," Africa: Journal of the International African Institute 68:2 (1998): 187.

${ }^{46}$ Christabel Gurney, "In the Heart of the Beast: The British Anti-Apartheid Movement, 19591994," in The Road to Democracy in South Africa: Volume 3: International Solidarity, ed. SADET (Pretoria: UNISA, 2008), 326. 
1980s, but only by framing issues according to public conceptions of South Africa's liberation struggle.

Where the narrative of child victimisation is most obvious is in the reporting from a conference held in Harare in September 1987 entitled, "Children, Repression and the Law in Apartheid South Africa." This international conference, organised by the AAM and convened by its President Trevor Huddleston, gathered together for the first time AAM members, ANC leaders, and grassroots activists from South Africa. Over 700 people attended, including ANC President Oliver Tambo, academics, journalists, NGO workers, doctors, lawyers, mothers, and community organizers. The conference thus represented one of very few moments where the transnational advocacy network forged between local and global activists became tangible and immediate. Most importantly, the conference invited a number of previously detained children from South Africa to speak and present their narratives unmediated to attendees.

The conference's goal was "to focus world attention on the plight of South Africa's youngest victims." ${ }^{47}$ It was deemed a success and credited with sparking "solidarity action all over the world," with children's testimonies being raised with British, Dutch, and American governments, as well as in the UN general assembly. ${ }^{48}$ The AAM also succeeded in extensively publishing the conference's proceedings. In a multi-page spread in Anti-Apartheid News, agency was granted to children who presented their stories, as journalists spoke of children's "obvious

${ }^{47}$ Victoria Brittain and Abdul S. Minty ed., Children of Resistance: On Children, Repression and the Law in Apartheid South Africa. Statements from the Harare Conference (London: Kliptown Books, 1988), 9.

${ }^{48}$ AAMA, MSS AAM 2203, Anti-Apartheid News, “Worldwide action for children,” May 1988. 
delight in having the opportunity to communicate with 'outsiders' pledged to support their struggle." ${ }^{49}$ Acknowledging the central role such children play in this network, and also the empowering effects sharing their stories could have, the publication recognised the "heroic courage" of these children "in their readiness to engage their ruthless oppressors in daily struggle." ${ }^{50}$ It even made mention of their specific ideological beliefs with regards to their adoption of the Freedom Charter. However, the publication simultaneously politically manipulated definitions of "childhood" to advance their argument. Using what David Rosen labels the "politics of age", the AAM cast all young activists who presented at Harare as "children". ${ }^{51}$ However, of six detainees whose testimonies were quoted at length only three were "children" according to the "strict 18" definition commonly employed by humanitarian organisations; two were eighteen-years-old and one was twenty-two. ${ }^{52}$

The British media also paid unprecedented attention to the conference, largely due to the efforts of Brittain. Yet in the media, all acknowledgements of children's agency and capabilities were removed. Reporting from the conference, Brittain wrote of "the horror of the impact of the tortured children themselves." She described an eleven-year-old who testified as a child "so small

49 AAMA, MMS AAM 2203, Anti-Apartheid News, "Voices from the Dark: Children tell of ordeals under State of Emergency," November 1987.

${ }^{50}$ AAMA, MSS AAM 2203, Anti-Apartheid News, "A Cry from South Africa: Free the Children from Apartheid,” November 1987.

${ }^{51}$ David M. Rosen, "Child Soldiers, International Humanitarian Law, and the Globalization of Childhood," American Anthropologist 109:2 (2007): 296.

52 AAMA, MSS AAM 2203, Anti-Apartheid News, “Testimonies of Torture,” November 1987. 
he barely reached the microphone," and who spoke "indistinctly" ${ }^{53}$ In a book produced on the conference proceedings, she wrote of how "on the platform, the youths were composed, dignified, as they told their stories," yet - drawing on western constructions of childhood as a period of dependency and need for protection - continued by stating that in being so composed these youths were clearly keeping their "psychological scarring well hidden." ${ }^{54}$ In the Observer, Glenys Kinnock, another AAM member and Harare attendee, wrote of how one child who testified was "the same age as my son," evoking readers empathy, but also suggesting that because the two youths were the same age they should be experiencing similar childhoods, regardless of cultural or political context. ${ }^{55}$

\section{$\underline{\text { Children's Voices }}$}

Such emphasis on victimisation contrasts directly with the original narratives of young activists themselves. When given the opportunity to publicly construct their own identities, at the conference in 1987 and almost thirty years later in oral history interviews, youth activists centred their narratives on agency and empowerment, rather than victimisation or innocence. It appears that most children invited to speak at Harare were living in exile at the time, mostly in Zambia, Tanzania, or Zimbabwe, likely as a result of their prohibited political activity. International attendees at the conference were surprised to hear that despite recounting horrible stories of torture and assault, these children nevertheless displayed courage, defiance and resilience qualities that were rarely mentioned in the British press. Authors reflecting on the conference

\footnotetext{
${ }^{53}$ Victoria Brittain, “A Scream from the Children,” The Guardian, 26 September 1987.

${ }^{54}$ Brittain, Children of Resistance, 36.

${ }^{55}$ Glenys Kinnock, “Apartheid's Children,” The Observer, 27 September 1987.
} 
wrote: "It appeared from their testimony that the children do not regard themselves as 'innocent victims', but that they plead 'guilty' to engaging in the protest campaigns in townships and schools to change apartheid." ${ }^{56}$ The children who testified tended to present their stories of detention and abuse in matter of fact terms, not dwelling on or overemphasizing their victimisation; several spoke of their resilience and continued political efforts despite their experiences in detention. ${ }^{57}$

Despite the decay and alteration of memory over time, former child and youth activists interviewed between 2014 and 2015 presented similar narratives to those recounted in Harare. ${ }^{58}$ In total, twenty-five interviews were conducted with former members of COSAS. Interviewees ranged in age from thirteen to eighteen when they joined the struggle against apartheid, and were all involved in collective action and political violence against state security forces. Twenty-one were detained and held in police cells for periods of two weeks to over six months, and the majority were abused or tortured while in detention, recounting stories of electric shocks, forced exercise, strangulation, and being beaten with whips, shoes, fists or metal pipes. Yet their narratives are not ones of victimhood or lost childhoods, but ones of agency that emphasise the empowering effect their participation had on them. They do not shy away from speaking about their involvement in collective action and political violence, but like children at the Harare Conference "plead guilty" to being deeply involved in the struggle. Speaking about her arrest at

\footnotetext{
${ }^{56}$ Brittain and Minty ed., Children of Resistance, 9.

${ }^{57}$ Ibid., 36-43.

58 These interviews were conducted by the author in Gauteng, South Africa, as part of a larger study on student politics in South Africa in the 1980s.
} 
the age of fourteen, one interviewee acknowledged, "before I got arrested, I was carrying a petrol bomb, we were going to burn a police house." ${ }^{\circ 9}$

Interviewees' recollections reflect academic arguments that despite their young age, the comrades displayed a "political precocity" ${ }^{60}$ Their descriptions of their complex networks of communication and methods of avoiding detection do not sound like the activities of naive children, but of highly organised and capable youths. Within Southern Africa, they developed their own communication networks, not only with the ANC in exile but also with civic organizations in the townships, trade unions, and parents and teachers' organizations. COSAS members were directly recruited into the ANC's underground networks, smuggled information and arms across the country's borders, and were integral to the ANC's attempts to make townships "ungovernable". In interviews, they place themselves at the centre of historical events, and highlight their indispensability to the liberation movement. Recounting a speech by ANC President Oliver Tambo over Radio Freedom, a female activist recalled, "I think it was 1986, when Oliver Tambo said, 'the Young Lions, they must roar!' So [that's] when we started to roar. We have to burn the schools, we have to boycott the classes... we have to make the world shake!" She continued, "Everything, it was under our control, and yes, we lost some of our comrades...others, they were detained...But we didn't stop because of that." ${ }^{\prime 1}$ For many, their eventual detention and brutalisation in police cells was evidence of the significant contribution they were making to the struggle. They recall with pride how several police vans would arrive at

\footnotetext{
${ }^{59}$ Interview with Nonkululeko, Diepkloof, 8 April 2014.

${ }^{60}$ Bundy, "Street Sociology,” 321.

${ }^{61}$ Interview with Nomsa, Diepkloof, 19 April 2014.
} 
their house to arrest one small child, or the precautions used when moving them from cell to cell in detention centres, "as if I'm Mandela's own child", one recounted. ${ }^{62}$ Similar narrative tendencies can be found in biographies of adult South Africans imprisoned during apartheid, which are "far richer than mere catalogues of inhumanity and exercises in victimology. They are also testimonies of surviving in desperate circumstances, of making meaning from suffering and above all of active people somehow able to strategize and resist." ${ }^{\prime 3}$

Interviews also suggest that political involvement could play a positive role in children and youth's lives, and help them cope with their volatile environment. As Jo Boyden argues, "there is some evidence that children who try actively to overcome adversity... are likely to be more resilient than children who accept their fate passively, especially in the long run." ${ }^{64}$ Similarly, Erica Burman contends that western constructions of childhood "[threaten] to ignore and undermine the positive role that political involvement may play in the lives of children coping with conflict and trauma." ${ }^{65}$ The long-term positive affects she speaks of are evident in former comrades' testimony. One male interviewee attributed his post-apartheid career success -

\footnotetext{
${ }^{62}$ Interview with Lucy, Fleurhof, 7 April 2014; Interview with Nosipho, Diepkloof, 8 May 2014.
}

${ }^{63}$ Don Foster and Donald Skinner, "Detention and Violence: Beyond Victimology," in Political Violence and the Struggle in South Africa, ed. N. Chabani Manganyi and André du Toit (London: Macmillan, 1990), 219.

${ }^{64}$ Jo Boyden, "Children under Fire: Challenging Assumptions about Children's Resilience," Children, Youth and Environment 13:1 (2003): 9.

${ }^{65}$ Erica Burman, "Innocents Abroad: Western Fantasies of Childhood and the Iconography of Emergencies," Disasters 18:3 (1994): 244. 
at a time when unemployment rates within the black population have reached upwards of forty per cent - to the leadership skills he learned as a student activist. ${ }^{66}$ Such effects are particularly noticeable in the recollections of female activists, who argue that being involved in the struggle enabled them to overcome much of the adversity facing young women in townships, and in particular mitigated feelings of physical insecurity. Speaking of endemic sexual violence, one female comrades stated, "No man can touch me here on the street again...being in the struggle made me know my rights." 67

\section{Global Discourse: A Means to an End?}

Within this transnational advocacy network, the discourses of local and global actors were not always at odds. Rather, when appealing specifically for support from British or western audiences, a number of South African activists appropriated western, globalised discourses of childhood and human rights for their own use. As Cooper argues, "Organizations that come to Africa with universalistic ideals in mind will likely find people to whom those ideals are relevant and useful in obtaining support and in associating one cause with a more widely shared one." 68 At the Harare conference, several African political leaders employed uncharacteristically western rhetoric. Across a range of speeches delivered to South Africans, then ANC president Oliver

${ }^{66}$ Interview with Joseph, Diepkloof, 14 May 2014.

${ }^{67}$ Interview with Ntebaleng, Diepkloof, 15 April 2014; similar narratives emerged in interviews with Khosi, Orlando East, 1 May 2014, and Zanele, Diepkloof, 12 April 2014.

68 Frederick Cooper, "Networks, Moral Discourse, and History," in Intervention and Transnationalism in Africa: Global-Local Networks of Power, ed. Thomas Callagy, Ronald Kassimir and Robert Latham (Cambridge: Cambridge University Press, 2001), 46. 
Tambo repeatedly saluted children and youth for their efforts and publicly recognised their indispensability to the liberation movement. Following the unbanning of the ANC in 1990, he stated, "I salute you, the young lions, for unflinchingly bearing the brunt of state repression." ${ }^{69}$ In 1985 he labelled youth "the pride of our nation", "relentless fighters for a South Africa that we can proudly call our own." Here, Tambo not only acknowledged youth's agency and centrality to the struggle, but also encouraged their further participation. While he was apologetic for the repression of youth that resulted from their ardent involvement in the struggle, he nevertheless did not emphasize their need for special protection or help from adults.

Yet, when speaking to an international audience, Tambo constructed South Africa's young activists in different terms. At Harare he stipulated, "Let the truth be told in all its gruesome detail. Let all humanity see the true face of apartheid, mirrored as it is in the glazed and staring eyes of the children it is starving to death and in the sightless eyes of those it has murdered." ${ }^{70}$ Removing the agency he previously granted to young activists, he spoke of children as "hapless and innocent." 71 His language was highly emotive and strongly emphasised the victimisation of children. He spoke of "endless rows of children's graves," "the barefoot child clothed in a sack that should carry produce," and "the mangled remains of the black child who

${ }^{69}$ Oliver Tambo, from speech delivered at ANC rally, 16 December 1990, www.anc.org.za. Accessed 16 July 2014.

${ }^{70}$ AAMA, MSS AAM 2203, Anti-Apartheid News, “A Cry from South Africa: Free the Children from Apartheid," November 1987.

${ }^{71}$ Oliver Tambo, Children of Resistance, 24-25. 
wanted only to play in the sun." ${ }^{72}$ None of these images were particular to, or prominent in, the South African context but would have called to mind for Western audiences familiar pictures of starving African children featured in British media during Ethiopia's famine just years before.

A similar shift is noticeable in the rhetoric of Frank Chikane, the secretary general of the South African Council of Churches and prominent United Democratic Front member, who spoke at the conference of the pain and suffering of children "being made to fight battles they should not be fighting as children." 73 Yet, in an academic publication the previous year, Chikane constructed children in active and rational terms, discussing their intricate and sophisticated plans to outwit security forces. He quoted a township resident speaking about the political awareness of her child, stating, "When my two-year-old daughter sees a military vehicle passing, she looks for a stone." Chikane explained, "The exposure of children to outrages in the townships has resulted in adaptive behaviour patterns. They are learning a different set of survival skills." 74 Yet children's ability to adapt and survive was excluded from Chikane's Harare speech, where he spoke of children's right to an innocent and happy upbringing when he stated that young detainees were "denied their right to be children," "violently forced by the conditions in the country to be adults before their time... They also want to have a chance to be children and

\footnotetext{
${ }^{72}$ Ibid., p. 25.

${ }^{73}$ Frank Chikane, Children of Resistance, 27.

${ }^{74}$ Frank Chikane, "Children in Turmoil: The Effects of the Unrest on Township Children," in Growing up in a Divided Society: The Contexts of Childhood in South Africa, ed. Sandra Burman and Pamela Reynolds (Johannesburg: Ravan Press, 1986), 343.
} 
develop naturally like other children. They want to play hide and seek."75 Here, Chikane drew specifically on western constructions of childhood, demonstrating an understanding of how different discourses are used for different audiences connected within the same advocacy network.

The explicit use of western rights discourse is also noticeable in interviews, though to a lesser extent. A number of interviewees made specific claims to their "rights" in terms of gender equality or their experiences of the struggle more broadly, stating "we didn't have rights"; "we cannot stay back while other students were fighting for our rights"; "we must fight for our rights"; or "We young lions, we thought maybe it is best for us to fight for our rights". ${ }^{76}$ The repeated use of this phrase suggests that comrades were aware of the human rights discourses used successfully in the global struggle against apartheid, or, at the least, that the proliferation of "rights" language in the global movement affected how comrades remembered their involvement in the struggle thirty years later. A similar case arose in interviews with demobilised child soldiers in Sierra Leone, who, when speaking to foreign NGO workers, strategically uses human rights language in an attempt to present themselves as victims and access better demobilisation

\footnotetext{
${ }^{75}$ Chikane, Children of Resistance, 27.

76 Quoted from the following interviews: Bessie, Johannesburg, 25 April 2014; Joshua, Diepkloof, 12 May 2014; anonymous female interviewee, Diepkloof, 1 May 2014; Ntebaleng, Diepkloof, 15 April 2014.
} 
packages ${ }^{77}$ Furthermore, post-apartheid South African society has become saturated with human rights talk; not only was the push for change in South Africa an international human rights project, but ANC leaders frequently framed their own struggles in rights discourse - often in seeking the approval of western leaders. The democratic country is thus the first "virtual product" of the human rights age and the norms it represents. Makau Mutua describes how since the transition, human rights have dominated almost every aspect of reconstruction, making South Africa "the first deliberate and calculated effort in history to craft a human rights state - a polity that is primarily animated by human rights norms." 78 It is thus not surprising that rights discourse is prevalent in comrades' memories.

It is not clear to what extent child and youth activists were aware of the transnational network forged on the basis of their testimony. When interviewees do make global connections, they speak of their solidarity with struggles in other African nations or Latin America rather than western efforts to end apartheid. Political education was a central tenet of COSAS philosophy, and efforts were made by the organisation's leaders to school its members in a wide range of global ideologies and histories. Yet emphasis was placed on learning about previous African leaders such as Patrice Lumumba, socialist heroes such as Fidel Castro, or the writings of Karl Marx, rather than on Western history or philosophy. ${ }^{79}$ While these young activists thus had a

${ }^{77}$ Susan Shelpler, "The Rites of the Child: Global Discourses of Youth and Reintegrating Child Soldiers in Sierra Leone," in Childhoods at the Intersection of the Local and the Global, ed. Afua Twum-Danso Imoh and Robert Ame (Basingstoke: Palgrave Macmillan, 2012), 175-177.

${ }^{78}$ Mutua, Human Rights, 126-133.

${ }^{79}$ Interviews with Musa, Diepkloof, 8 May 2014; and Sello, Diepkloof, 14 May 2013. 
global outlook, and sought to forge connections beyond their borders, they saw themselves as connected to others through their left-wing ideology and struggle for liberation rather than a shared commitment to liberal humanitarian principles.

Furthermore, there is evidence to suggest that information about the AAM's efforts to protect South African children did not easily make it past the apartheid state's strict censorship. In 1986, a former COSAS member visited Britain to speak to the National Union of Students, and made a clear statement about the lack of information flowing from the AAM to the comrades: "We don't get much information at home about the way British students are supporting us...I was inspired to realise that all of them are against the apartheid system and want it destroyed." 80 One interviewee named Musa, a COSAS leader, stated that he personally was aware of the AAM's efforts, and that young activists in South Africa celebrated the AAM's organising of a concert in support of the liberation struggle. ${ }^{81}$ But the lack of reference made to the AAM or global struggle against apartheid in other interviews suggests that knowledge of this network was perhaps limited to those in leadership positions. Nevertheless, Musa reminded me that all activists in South Africa were encouraged to have a global outlook, as international solidarity was defined by the ANC as one of the four pillars of their struggle, along with armed operations, mass mobilisation, and underground political work. ${ }^{82}$

\section{Conclusion}

80 AAMA, MSS AAM 2203, Anti-Apartheid News, "Beyond the threshold of fear," January/February 1986.

${ }^{81}$ Interview with Musa, Diepkloof, 8 May 2014.

${ }^{82}$ Ibid. 
A closer look at young activists and the global anti-apartheid movement reveals a web of connections between multiple individuals, groups and geographical sites that complicates spatial conceptions of empire and postcolonial humanitarianism. Using a network approach to analyse South Africa's transnational liberation struggle allows one to see these lateral, or at times unreciprocated, connections rather than just those forged between former empires and colonies. Such an approach to global and imperial history can also expose not just how metropole and periphery were mutually constituted, but also how they were mis-constituted through uneven exchanges or overlooked connections. Such analysis is possible when the experiences of elite and local or subaltern actors are given equal consideration, and when sources are interrogated for asymmetry and exclusion.

In studies of international solidarity against apartheid, it is clear that certain voices were privileged above others. Britain's efforts are more predominant than any other, and particularly more so than countries on the other side of Cold War rivalries. Recently, scholars have attempted to demonstrate the truly global nature of the anti-apartheid movement, by examining solidarity in other Western European countries, the global "South", Australia, and the Soviet bloc. ${ }^{83}$ Yet the prevailing narrative remains that of British, and to a lesser extent American, anti-apartheid efforts, despite the obvious ties between African liberation movements and the countries that supported their armed struggles such as Tanzania, Cuba and the Soviet Union. Such a tendency not only reflects the persistent dominance of Anglophone networks in imperial and global history, but also is indicative of the difficulties of conducting research in such countries; for

${ }^{83}$ Lisa Brock, V and Gosse, and Alex Lichtenstein, "Editors' Introduction," Radical History Review 119 (2014): 2. 
example, many Russian archives relating to their anti-apartheid efforts remain classified or are difficult to access. ${ }^{84}$ Additionally, Britain's dominance within the global anti-apartheid movement can be partially explained by its close historical ties to South Africa, as the country's colonial connections played a crucial role in its postcolonial networks. ${ }^{85}$ Much more research is needed into the ways in which these multiple and often conflicting geographical centres of the anti-apartheid movement were connected to, and disconnected from, each other given their different histories and politics, and their operation at a time of such great global tension. ${ }^{86}$

Within global solidarity networks, the relationships between various actors are by no means always those of convergence and cooperation, as the dissemination of information becomes a site of internal struggle. As elite actors within networks frame issues in ways that make them more accessible to public audiences, local actors often lose control over their own narratives. This article has focused on the limits and tensions within one facet of this network: the connections forged between the British AAM and young grassroots activists in South Africa. Here, it was western-based activists, rather than those on the ground in the townships, who ultimately had the power to shape international public understandings of apartheid. This article does not seek to question the principles or motivations of AAM members, but to examine their methods and the power dynamics they reinforced. The problem with narratives of victimisation

${ }^{84}$ Limb, Knight and Root, “The Global Anti-Apartheid Movement," 166.

${ }^{85}$ For more on empire as a historical lens see Mrinalihi Sinha, "Projecting Power: Empires, Colonies, and World History,"; in A Companion to World History, ed. D. Northrop (Chichester: Wiley-Blackwell, 2012), 258-271.

${ }^{86}$ Limb, Knight and Root, “The Global Anti-Apartheid Movement,” 174. 
were not that they were false - children were detained, abused, and deprived of their human rights - but that they denied children's resourcefulness, resilience, political agency, and capacity to cope with their environment. The greatest consequence of such advocacy imagery is that it denies political agency to children, and elicits "sympathy for passive suffering rather than support for active (including armed) struggle." 87 In the South African case, denying youth agency also misrepresented events unfolding on the ground:

The focus on children as merely victims of political violence...fails to come to terms with the basic ways in which we have come to live in "the Time of the Comrades," with the mass revolt of the school children contributing in crucial ways to the political struggle. Any discourse which would engage with the aims of that struggle...must take seriously the social agency of these children as capable of responsible, rational and violent actions themselves as well as suffering the effects of political violence. ${ }^{88}$

Discourses, such as those of human rights and child victimisation utilised by the AAM, are central to network functioning, and help to provide cohesion between diverse actors spread across the globe. ${ }^{89}$ Yet it is important to ask whose voices these discourses represent. While much attention has been paid by academics over the past two decades to the forces that connect us, not enough has been focused on disconnecting forces, or the asymmetrical functioning of transnational networks. The power imbalances evident in this case study are not unique to the

\footnotetext{
${ }^{87}$ Burman, "Innocents Abroad," 241.

${ }^{88}$ Manganyi and du Toit "Editorial Introduction," 23.

${ }^{89}$ Cooper, "Networks, Moral Discourse, and History," 24.
} 


\begin{abstract}
AAM, but are present in humanitarian networks throughout history. ${ }^{90}$ Yet, when analysing transnational advocacy networks, "one need not fall into a dichotomy of global and local, between allegedly universal principles and supposedly particular communities, for the historical record is filed with networking and discursive formations situated in between." ${ }^{91}$ Local activists in the global struggle against apartheid may have lost control of their narratives as they were framed according to global principles. Yet, they too were strategic and skilful users of information framing, and employed different discourses depending on their audience and objectives, appealing to the universal and emotive appeals of human rights and child victimisation.
\end{abstract}

\footnotetext{
${ }^{90}$ Rob Skinner and Alan Lester, "Humanitarianism and Empire: New Research Agendas," The Journal of Imperial and Commonwealth History 40:5 (2012): 740.

${ }^{91}$ Cooper, "Networks, Moral Discourse, and History," 46.
} 